\title{
ЛЕКСИЧЕСКИЕ ОСОБЕННОСТИ ТОПОНИМОВ ОВЮРСКОГО РАЙОНА ТУВЫ"
}

\section{Любовь С. Кара-оол}

Тувинский государственный университет, Российская Федерация,

\section{LEXICAL FEATURES OF MICROTOPONYMS OF OVYUR RAYON OF TUVA}

\author{
Lyubov S. Kara-ool \\ Tuvan State University, \\ Russian Federation,
}

В статье анализируются лексические особенности топонимов (названий населенных пунктов) Овюрского района Тувы. Топонимы объединены в лексико-семантические группы, по каждому топониму уточнено, какой географический объект он называет, его лексическое происхождение; указано какие родоплеменные группы тувинцев жили или живут в рассматриваемой местности. Источниковую базу исследования составили полевые материалы автора, собранные в 2015 и 2017 г2. во время комплексных экспедиций, также приведены примеры из «Топонимического словаря Тувы» Б. К. Ондар.

Выделены следующие группы топонимов Овюра: связанные с растительным миром (Ак-Чыраа, Артыштыг-Хем, Адыр-Тал и др.); связанные с отличительными признаками объектов местности (Сарыг-Хөл, Сарыг-Хая, Кара-Дөргүн, Чаа-Суур и др.); связанные с природными особенностями местности (Адырган, Думчук ужу и др.); связанные с животным миром района (Торгалыг, Хайдагай-

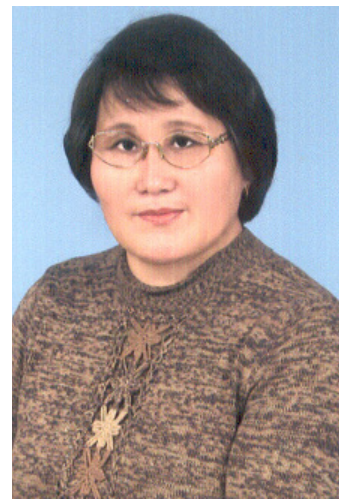

The article investigates the lexical features of the toponyms (more specifically, settlement names) of the Ouyur rayon of Tuva. Toponyms are combined into lexicosemantic groups; for each toponym we specify the geographic object it refers to, and the lexical origin of its name. It is also indicated which clans and tribal groups of Tuvans lived or live in the area in question. The sources of the research were the field materials collected by the author during comprehensive expeditions in 2015 and 2017. Some examples are also drawn from "A Toponymical Dictionary of Tuva" by B. Ondar.

On the basis of our study, we have been able to identify the following groups of Ovyur toponyms: those associated with the flora (Ak-Chiraa, Artyshtyg-Khem, Adyr-Tal, etc.); with some distinctive features of the sites (Saryg-Khul, SarygKhaya, Kara-Durgen, Chaa-Suur, etc.); with the natural features of the area in general (Adyrgan, Dumchuk uzhu, etc.); with the fauna of the region (Torgalyg, Haidagayty, etc.); with ethnonyms (Kalga-Keii, Moldug-Khem, etc.); with mineral

\footnotetext{
* Исследование выполнено при поддержке РФФИ, проект «Социокультурные, этногенетические и этноантропологические исследования родовых групп народов Центральной Азии (на примере Республики Тыва, Республики Алтай, Республики Калмыкия, Монголии и Синьизян-Уйгурского Автономного округа Китая)», грант 16-21-03002 / The study was supported by the Russian Foundation for Basic Research, project title "Sociocultural, ethnogenetic and ethnoanthropological studies of tribal groups of the peoples of Central Asia (on the example of the Republic of Tuva, the Republic of Altai, the Republic of Kalmykia, Mongolia and the Xinjiang Uygur Autonomous Region of China)" (grant 16-21-03002).

Кара-оол Любовь Салчаковна - кандидат филологических наук, доцент кафедры теории и методики языкового образования и логопедии Тувинского государственного университета. Адрес: 667000, Россия, г. Кызыл, ул. Ленина, д. 36. Тел.: +7 (394-22) 2-19-69. Эл. адрес: lkaraool61@mail.ru

Kara-ool Lyubov Salchakovna, Candidate of Philology, Associate Professor, Department of Theory and Methods of Language Education and Speech Therapy, Tuvan State University. Postal address: 36 Lenin St., 667000 Kyzyl, Russian Federation. Tel.: +7 (394-22) 2-19-69. E-mail: lkaraool61@mail.ru
} 
ты и др.); связанные с этнонимами (Калга-Кежии, Моолдуг-Хем и др.); связанные с полезными ископаемыми (Дус-Даг); связанные с событиями из жизни овюриев (Кара-Туруг, Солчур).

Топонимическое своеобразие территории Овюрского района заключается в том, что в нем присутствуют разные тенденции присвоения географических имен - по особенностям кочевания и оседлой жизни. Наименования сел и стоянок животноводов связаны с названиями рек, гор и других географических объектов. В структурном и этимологическом отношениях значительную часть топонимов Овюра составляют собственно тувинские сложные слова, компоненты которых выражены общетюркскими, тюрко-монгольскими или монголо-тюркскими, монголо-китайскими словами.

Ключевые слова: топоним; топонимия; Тува; Овюрский район; тувинский язык; заимствования; монгольский язык; монголизм resources (Dus-Dag); and finally, those related to the events in the life of the Ovyurians (Kara-Turug, Solchur).

The toponymic originality of the rayon lies in the fact that there have been a number of trends in appropriating geographical names - trends which refer to differing elements of nomadic and sedentary lifestyles. The names of villages and cattle breeders' campsites are associated with the names of rivers, mountains and other geographical objects. In structural and etymological relations, a significant part of the Ovyur toponyms are actually Tuvan compound words, the components whereof are expressed by common Turkic, TurkicMongolian or Mongolian-Turkic, and MongolianChinese words.

Keywords: toponym; toponymy; Tuva; Ovyur rayon; Tuvan language; loanwords; Mongolian; mongolism

\section{Введение}

Топонимия с ее разнообразием и богатством, общепонятностью и загадочностью до сих пор остается значимым не только для языкознания, но и для общества в целом, так как она тесно связана с историей и культурой народа, с его историческими контактами с соседними государствами, географическими и биологическими особенностями территории. Поэтому может быть предметом изучения этнографии и истории, географии и биологии, археологии и физики, фольклористики и лингвистики и т. д. При глубоком изучении топонимов можно узнать не только лексико-семантические особенности собственных имен, но и какие слои населения и родоплеменные группы представлены в исследуемой территории, к каким языковым и профессиональным группам принадлежит население, какова этническая история территории, какую религию исповедовали и т. д.

Целью данной работы является лексический анализ топонимов (названий населенных пунктов) отдельного района Тувы, а именно - Овюрского района (Овюра). Топонимы будут объединены в лексико-семантические группы. По каждому топониму будет уточнено, какой географический объект он называет, его лексическое происхождение, также указано, где это возможно, какие родоплеменные группы тувинцев жили или живут в рассматриваемой местности: в связи с развалом совхозов в 90-х годах XX столетия, а также с тем, что значительная часть современных потомков тувинских родоплеменных групп перестали заниматься исконным занятием своих предков животноводством, при котором вели кочевой образ жизни, многие стоянки перестали существовать, поэтому наши информаторы иногда не могли сказать, какому роду принадлежала местность. 
Источниковую базу исследования по топонимам Овюра составили полевые материалы автора, собранные в 2015-м и 2017-м годах во время комплексных экспедиций при поддержке Российского фонда фундаментальных исследований по проектам «Диалог цивилизаций народов Центральной и Внутренней Азии: история, культура и парадигмы существования» (грант 15-21-03002) и «Социокультурные, этногенетические и этноантропологические исследования родовых групп народов Центральной Азии (на примере Республики Тыва, Республики Алтай, Республики Калмыкия, Монголии и Синьцзян-Уйгурского Автономного округа Китая)» (грант 16-21-03002). В 2015 г. автор изучала западную территорию Овюра, а в 2017 г. - юго-восточную часть района. Также привлечены примеры из двух изданий «Топонимического словаря Тувы» Б. К. Ондар (Ондар, 2004, 2007).

\section{Из истории изучения вопроса}

K настоящему времени в тюркологии появилась большая литература по топонимии, которая в количественном отношении занимает одно из первых мест, и в ней хорошо представлены общие и региональные исследования: статьи, кандидатские диссертации, словари, монографии и т. д. (Молчанова, Мурзаев, 2005).

Топонимы Тувы впервые были зафиксированы в орхоно-енисейских памятниках (Кормушин, 1997, 2008), некоторые географические объекты отмечены в картах русских путешественников Л. Э. Шварца (1858), Н. Ф. Веселкова (1871). А подлинно научное изучение Тувы, языка, культуры, истории и этнографии ее народа связано СX в., начало которого положено в последниедесятилетия XIX в. И, в первую очередь, это неоценимые материалы экспедиций Г. Н. Потанина (Потанин, 2007), А. В. Потаниной (Потанина, 2003), Е. К. Яковлева (Яковлев, 1900), Н. Ф. Катанова (Катанов, 1903), Вс. Родевича (Родевич, 2003), Д. Каррутерса (Каррутерс, 2007), Г. Е. Грумм-Гржимайло (Грумм-Гржимайло, 2007), Ф. Кона (Кон, 1934), а также археологических исследований М. Х. Маннай-оола (Маннайоол, 1961), А. Д. Грача (Грач, 1980) и др. Топонимы, зафиксированные в данных работах, являются для нас ценным материалом, имеющим научный интерес и в наше время.

Топонимия тувинского языка специально исследована учёными-тувиноведами: Ш. Ч. Сатом (Сат, 1969), Б. И Татаринцевым (Татаринцев, 1973, 1977ab, 1993), М. В. Бавуу-Сюрюн (Бавуу-Сюрюн, 2005), Н. Д. Сувандии (Сувандии, 2004, 2013, 2015) и др.

Ведущее же место в этом направлении занимают труды Б. К. Ондар, которая изучила историю исследования топонимов Тувы и посвятила данной проблеме целый ряд статьей (Ондар, 1999, 2000, 2001, 2003, 2005 и др.), опубликовала монографии «Тувинская топонимия. Сопоставительный анализ топонимии 
Тувы с топонимией Южной Сибири и других тюркоязычных территорий» (Ондар, 2008а) «Тувинская топонимия: проблемы, поиски, решения. Проблемы преподавания русского языка в вузе и в школе» (Ондар, 2008b), выпустила «Краткий словарь гидронимов Тувы» (Ондар, 1995) и «Топонимический словарь Тувы» в двух изданиях (Ондар, 2004, 2007).

Именно в статьях Б. К. Ондар топонимы Овюра впервые рассматриваются как объект лингвистического анализа. Например, название районного центра Овюра - Хандагайты (в монгольском ‘с лосью’ или ‘сохатый’) (Ондар, 1999: 49); названия рек из Овюра - Мургуску (монгольское бургаас(ан) - 'ива, тальник') и Чоза (монгольское зос - ‘земляная краска') (Ондар, 2000: 56-57); название

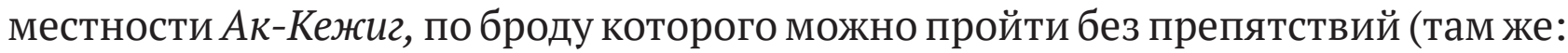
20); названия минеральных источников Талдыг-Чарык - 'расщелина с зарослями тальника', Улаатай - ‘тополиный’ (Ондар, 2006: 51-59). Значительная часть топонимов Овюра зафиксированы в «Топонимическом словаре Тувы», автор которого указала какой географический объект называет тот или иной топоним с уточнением лексического значения его компонентов (Ондар, 2004, 2007).

Мы сочли нужным систематизировать топонимы Овюра по их лексико-семантическим группам с дополнением того, какой географический объект еще называет тот или иной топоним, какой родоплеменной группе принадлежит местность, а также определить этимологию топонимов.

\section{Лексико-семантические особенности топонимов Овюра}

\section{1. Топонимы, связанные с растительным миром}

Aк-Чыраа [акчыра:] - буквально «белый ивняк»: названия местности (чер ады), урочища (чыраалыг чер) и населённого пункта (чурттакчылыг чер, суур), находящегося на территории Овюрского района (Ондар, 2007: 99).

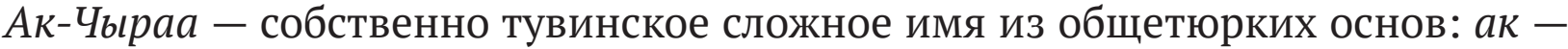
‘белый', ‘чистый’, ‘невинный’, ‘прекрасный’ (Севортян, 1974: 116-117); чыраа 'ивняк, заросли ивы', 'хворостина' (Тувинско-русский словарь, 1968: 558), встречается в тюркских языках Сибири, смотри алтайский јыраa - 'кустарник', хакасский чыра - 'название кустарника', тофаларский hsыraa - 'карликовая берёза’ (Рассадин, 1971: 200).

Село Ак-Чыраa находится на приграничной территории с Монголией и известно тем, что на его территории находятся древние курганы, которые были исследованы ещё в 1960-х гг. (Маннай-оол, 1961; Грач, 1980: 13-15).

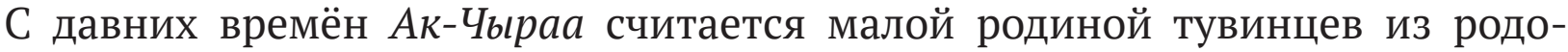
племенной группы тумат. Туматы есть и у хакасов, алтайцев, якутов, бурят, халхасцев и южных монголов, они «жили в пределах страны кыргызов и были чрезвычайно воинственным племенем и войском» (История Тувы, 2001: 157), 


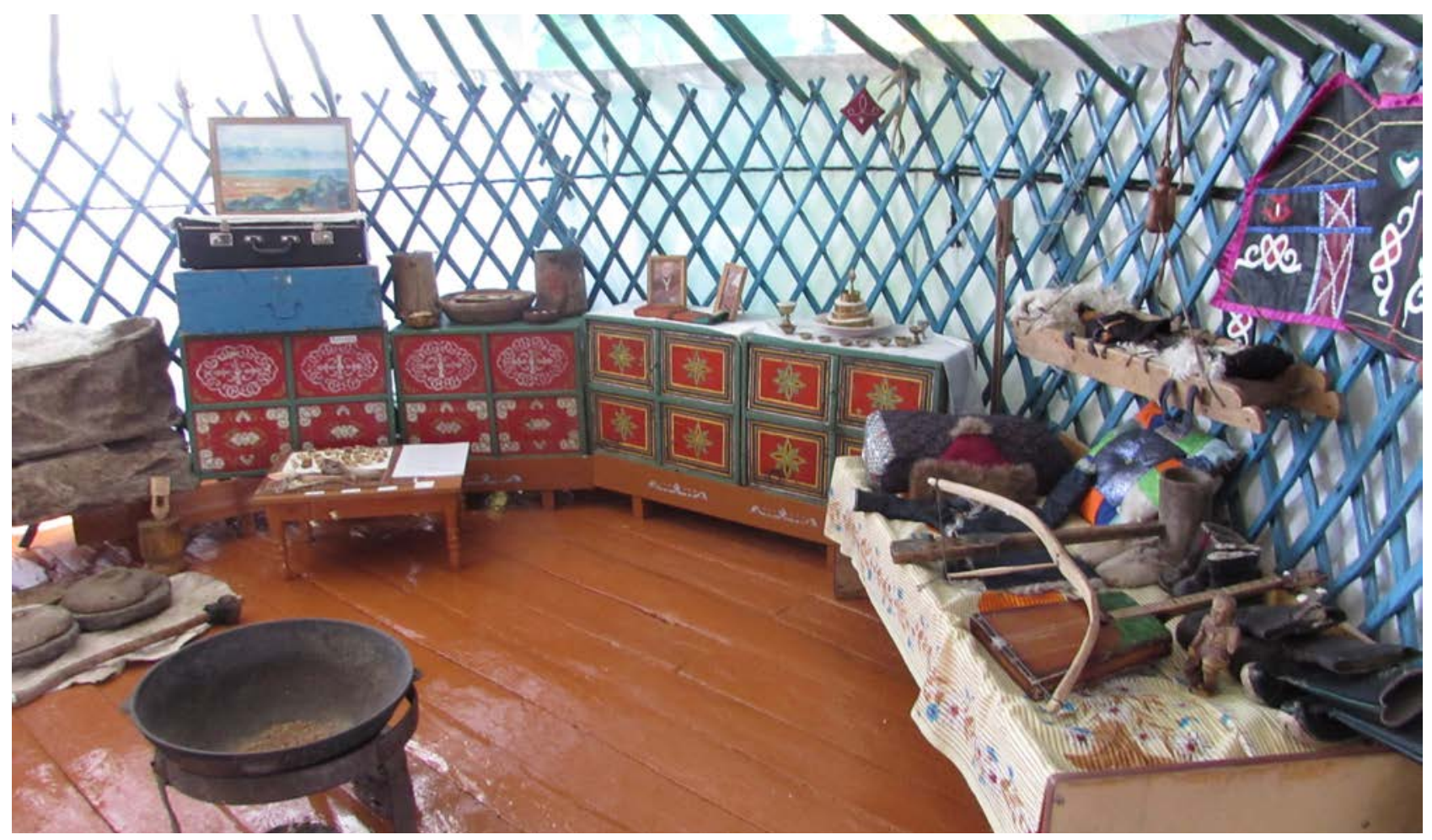

Фото 1. Краеведческий отдел школьного музея с. Саглы. Фото автора, 2015 г.

Photo 1. Local studies section, School museum, village of Sagly. Photo by the author, 2015.

по сведениям наших информаторов, в данной местности раньше жили и представители рода тулуші .

Название села $A \kappa$-Чыраа тесно связано с другим собственным именем СарыгХөл (см. ниже): когда уточняют название села, говорят: «Сарыг-Хөл сумузунуң Ак-Чыраа сууру» - «село Ак-Чыраа Сарыг-Хольского сумона».

Артыштыг-Хем [артыштыгхэм] - буквально «можжевельниковая река», т. е. 'река с можжевельником'. В «Топонимическом словаре Тувы» Б. К. Ондар отмечено как название реки (Ондар, 2007: 125). Так называют и летнюю стоянку животноводов - ‘чайлаг'. Собственно тувинское сложное слово: артыш - ‘можжевельник’+аффикс -тыг, обозначающий предмет обладания. Э. В. Севортян артыш ардуч ардыч ардыш ыртыш - 'можжевельник', 'ель, ёлка', ‘горное растение' считает правомерным сравнивать с персидским ӓрдӓж, отметив также мысль о монгольском происхождении, которая, по его мнению, «имеет внеязыковую реальную опору в применении можжевельника как дезинфицирующего средства...» (Севортян, 1974: 173-174); хем - 'река, речной’ (Тувинско-русский словарь, 1968: 473), древнетюркское слово, смотри кем - 'река' (Древнетюркский словарь, 1969: 297).

${ }^{1}$ Данный этноним в современном тувинском языке имеет несколько вариантов правописания түлүш, тулуш, тюлюш, дулуш, дюлюш. 
По нашим сведениям, в последние дни весны в Артыштыг-Хем перекочевывают животноводы из родоплеменных групп донгак, монгуш, куулар, сат $u$ тулуш.

Адыр-Тал [адырт'ал] ${ }^{1}$ - буквально «ответвление ивы», т. е. 'ива с ответвлениями'; название местности (чер aды) в Овюрском районе, не отмеченное в топонимическом словаре Б. К. Ондар (Ондар, 2007); собственно тувинское сложное слово из общетюркских основ: aдыр - 'развилина; ответвление; ветка', 'приток', 'отрасль; сфера' (Тувинско-русский словарь, 1968: 38). Широко представлен в топонимии Тувы как самостоятельный топоним, а также в составе собственных имен-топонимов (Ондар, 2007: 15), в древнетюркском адыр - 'отделение, ответвление, развилина' (Древнетюркский словарь, 1969: 11); тал - 'ива; тальник; лоза' (Тувинско-русский словарь, 1968: 404) - слово отмечено во всех кыпчакских, частично в огузских, в уйгурских и северовосточных тюркских языках. По Э.В.Севортяну, для тал/дал старейшим является значение 'ветвь, ветка' Севортян, 1980: 131).

Бора-Шай [порашай] ${ }^{2}$ - буквально «серый чай»: название реки (хем) и местности (чер) (Ондар, 2007: 169), т. е. летней (чайлаг) и зимней стоянки (кыштаг); собственно тувинское сложное слово: бора - 'серый', 'сивый' (Тувинско-русский словарь, 1968: 113), 'низкого качества' (Толковый словарь ..., 2003: 286), монголизм, смотри бор - 'серый’, 'сивый’ (Севортян, 1978: 173; Большой академический ..., 2001a: 264): бора метафорически использовано в значении 'забелённый (молоком)'; шай - 'чай' (Тувинско-русский словарь, 1968: 564), китаизм (Большой академический ... , 2002: 246). На территории Монголии река Бора-Шай называется Боршоо-Гол - ‘серый чай': название реки в тувинском и монгольском языках мотивируется с цветом воды, напоминающей чай, забеленный молоком.

В Бора-Шай перекочёвывают монгуши, куулары, саты и тулуши. По сведениям наших информаторов, монгуши являются коренными жителями данной местности.

Kaра-Дыт [карадыт] - буквально «чёрная лиственница»: название реки (хем) (Ондар, 2007: 237), а также летней стоянки, находящейся на берегу одноименной реки; собственно тувинское сложное слово из общетюрких основ: кара 'чёрный, тёмный', ‘вороной’, в полиграфии это слово также означает 'жирный’, ‘бесснежный’, в устной речи - 'простой’, в переносном значении - 'мрачный, тяжёлый’ (Тувинско-русский словарь, 1968: 226), а также 'тёмный, дремучий’, 'смуглый’, ‘без молока, не забелённый молоком', 'постный, нежирный',

\footnotetext{
${ }^{1}$ В начале тувинского слова тал «сильная фонема, произносящаяся всегда глухо и с относительно заметным придыханием» (Сравнительно-историческая грамматика ..., 2002: 624).

${ }^{2}$ Несоответствие буквы «д» и звука [т] или буквы «б» и звука [п] в начале слова объясняется тем, что в анлауте слова слабая фонема произносится «с весьма слабым озвончением», т. е. реализуется как ненапряженный непридыхательный глухой или полузвонкий аллофон (там же: 624).
} 
'немытый, грязный', ‘почерневший, бедный’, ‘плохой, злой, злонамеренный’, 'мишень' (Толковый словарь ..., 2003: 66).

Кара зафиксировано во всех тюркских языках (Этимологический словарь ... , 1997: 286), метафорически употреблено в значении 'густой' - у лиственницы заросшая крона; дыт - 'лиственница' (Тувинско-русский словарь, 1968: 195; Толковый словарь ..., 2003: 562) отмечено ещё в древнетюркском (Махмут Кашгари) tït - 'лиственница' (Древнетюркский словарь, 1969: 569), распространено в тюркских языках Саяно-Алтая: см. алтайский, хакасский, шорский, тофаларский тыт - 'лиственница' (Татаринцев, 2002: 322-325).

По нашим данным, с давних времен в Кара-Дыт в летнее время перекочевывают монгуши, саты и донгаки.

Теректиг - буквально «тополиный»: название реки и местности в БайТайгинском, Баруун-Хемчикском и Дзун-Хемчикском районах (Ондар, 2007: 387), а также название летней и зимней стоянки в Овюре:дериват (производное слово) терек - 'тополь' (Тувинско-русский словарь, 1968: 412), общетюркское слово (Древнетюркский словарь, 1969: 553; Сравнительно-историческая грамматика ..., 2001: 105, 134). Другое название местности - Улаатай.

В данной местности живут животноводы из родовых племён - донгак и монгуш.

Улаатай [ула:тай] - название реки, впадающей в озеро Убсу-Нур, и минерального источника, находящегося на северо-восточной части районного центра Хандагайты (Ондар, 2007: 404), а также название летней и зимней стоянки. Улаатай связывают с монгольским улиас(ан) - 'осина', 'тополь' (Большой академический ..., 2001с: 324).

В данной местности живут животноводы из родовых племён донгак и монгуш.

Хаaктыг-Apm [ха:ктыгарт] - буквально «тальниковый перевал», т. е. перевал с тальником 'арт'. Не зафиксирован в топонимическом словаре Б. К. Ондар. Собственно тувинское слово из общетюркских основ: хаак с афф. - тыг, обозначающим предмет обладания. В тувинском хаак - 'мелкий тальник' (Тувинской-русский словарь, 1968: 458) в результате выпадения интервокального согласного появился долгий гласный, а в начале слова наблюдаем чередование согласных $x / /$, смотри на общетюркский қавақ - 'тополь', 'липа', 'чинара', ‘ива; тальник' и подобное (Этимологический словарь ..., 1997: 170171); apm - ‘перевал’ (Тувинско-русский словарь, 1968: 69), в других тюркских языках apm - 'горный перевал, проход', 'нагорье, круча, хребет', 'плоскогорье' (Севортян, 1974: 179).

Хам-Дыт [хамдыт] - буквально «шаман лиственница», т. е. 'священное дерево’ (Тувинско-русский словарь, 1968: 466): река в Сут-Хольском, ПийХемском, Тоджинском районах, местность - в Овюрском, Улуг-Хемском и 
Тандинском районах (Ондар, 2007: 441-442), летняя стоянка вблизи ЧааСуура. В представлении тувинцев хам $\partial ы m$ - лиственница с причудливой формой, густо переплетенными ветвями в виде гнезда, имеющий своего духа или хозяина: хам - 'шаман / шаманский' (Тувинско-русский словарь, 1968: 466), с возрождением шаманизма с 1990-х годов слово перешло в разряд общеупотребительных, общетюркское слово (Древнетюркский словарь, 1969: 413; Этимологический словарь ... , 1997: 240-241]. Общетюркий дыт ‘лиственница' (Древнетюркский словарь, 1969: 569; Татаринцев, 2002: 322-325), смотри выше.

На летней стоянке Хам-Дыт живут представители родовой племени кыргыс.

Шокар-Хараган [шокархараган] - букв. 'пёстрый караганник': местность в Бай-Тайгинском районе (Ондар, 2007: 518), осенняя стоянка күзег в Овюрском районе; собственно тувинское слово из монгольского и общетюркого основ: шокар - 'пёстрый', 'разрисованный, украшенный орнаментом', 'разнородный по составу, сборный’ (Тувинско-русский словарь, 1968: 577), монголизм, смотри монгольское цоохор - 'пёстрый, пятнистый, рябой', 'конопатый', 'корявый', ‘зернистый’, ‘чубарый’ (Большой академический ..., 2002: 262); хараган ‘караганник' (Тувинско-русский словарь, 1968: 469), смотри общетюркский қараған - 'желтая акация', 'кустарник', 'ракита' (Севортян, 1997: 293)

По нашим сведениям, Шокар-Хараган считается осенней стоянкой животноводов из рода монгуш.

2. Топонимы, связанные с отличительными признаками объектов местности

Сарыг-Хөл [сарыгхөл] - буквально «жёлтое озеро»; в названии озера (хөл) на территориях Тоджи и Овюра (Ондар, 2007: 352) отразилась характеристика по существенному признаку - цвету. Собственное тувинское сложное имя из общетюркского сарыг - 'жёлтый', 'русый', 'рыжий', 'соловый', 'саврасый', ‘сивый’, 'седой, белый’, ‘бледный’, ‘яркий, красный’, ‘светлый, красивый’, 'наливной, спелый’, 'желток’ (Этимологический словарь ..., 2003: 206-207) и köl - 'озеро’ (Древнетюркский словарь, 1969: 313). Лексема сарыг использована в переносном значении 'мутный, талый’ (Ондар, 2007: 352), которое не отмечено в «Этимологическом словаре тюркских языков» (Этимологический словарь..., 2003: 206) и в «Тувинско-русском словаре» (Тувинско-русский словарь, 1968: 369), и название озера переводится как «мутное озеро».

У озера Сарыг-Хөл есть и другое название - Амдайгын, в «Топонимическом словаре Тувы» зафиксировано как Амдайгын-Хөл (Ондар, 2007: 113): амдайгын монголизм, смотри монгольское амтайхан - 'сладенький, приторный; сладкий, сахарный', 'вкусный, приятный’, 'слащавый, елейный’ (Большой академический ... , 2001а: 93). Б. К. Ондар предположила, что название озера Амдайгын связано со слабоминерализованной лечебной водой озера (Ондар, 2007: 114), приятного на вкус. 
По нашим сведениям, до 1990-х годов Сарыг-Холом (совхоз) называли село Ак-Чыраа, и на территории озера Сарыг-Хол раньше жили только туматы, в настоящее время - туматы и тулуши.

Сарыг-Хая [сарыгхайа] - буквально «жёлтая скала»; название горы в МонгунТайгинском, Барун-Хемчикском и Бай-Тайгинском районах (Ондар, 2007: 352), в Овюре Сарыг-Хая - гора и местность. Собственно тувинское сложное слово из общетюркского сарыг - 'жёлтый' (Этимологический словарь ..., 2003: 206207) и хая - 'скала' (Тувинско-русский словарь, 1968: 471), слово представлено ещё в древнетюркских памятниках gaja - 'скала' (Древнетюркский словарь, 1969: 406).

Как сообщили нам информанты, в Сарыг-Хая осенью перекочёвывают чабаны из родов донгак, чоза доңгак и куулар.

Кара-Дөргүн [карадөргүн] - буквально «черная речка с небольшим лесочком», т. е. 'речка в сухой степи, окруженный зеленью': речка, урочище (чер) и стоянка вблизи села Солчур Овюрского района (Ондар, 2007: 237). Собственно тувинское сложное имя из общетюркского кара - ‘чёрный, тёмный’ (Севортян, 1997: 286); дөргүн - 'чёрная речка, берущая начало в степи и окружающий ее лес' (Тувинско-русский словарь, 1968: 179), а также 'речная долина с пастбищами в горно-таёжных районах', 'группа деревьев, растущая в отдалении от леса, перелесок’ (Татаринцев, 2002: 246). Б. И. Татаринцев предположил, что «дөргүн и төргүн - тюркские по происхождению слова, имеющие узкий ареал распространения...» (Татаринцев, 2002: 247; курсив источника. - Л. К.).

Издавна животноводы из родов кара-монгуш и куулар в осеннее и зимнее время перекочевывают в Кара-Доргун.

Чаa-Суур [ча:су:р] - буквально «новое село»: населённый пункт (Ондар, 2007: 467), село. Собственно тувинское сложное слово из общетюркого чаа 'новый’, 'свежий', 'парной', 'недавно, только что' (Тувинско-русский словарь, 1968: 503): долгий гласный появился в результате выпадения интервокального согласного в древнетюркском јаүї - 'новый’ (Рассадин, 1971: 209); суур - 'село', 'сельский’, ‘посёлок', ‘посёлковый’ (Тувинско-русский словарь, 1968: 393), монголизм, смотри монгольское суурь - 'стан; поселок; место, где живут оседло’ и 'основание; база', ‘подставка', 'место на которой можно сидеть', 'престол' (Большой академический ..., 2001с: 136-137).

В селе Чаа-Суур в основном живут тувинцы из рода тулуш, кыргыс.

$\boldsymbol{A k}$-Кежиг [акэжиг] - буквально «белая переправа» или «белый брод»: название местности в Овюрском и Эрзинском районах (Ондар, 2007: 92). По нашим материалам, до развала Советского Союза, здесь была молочная ферма совхоза, а сейчас это осенняя стоянка күзег, собственно тувинское сложное слово из общетюркого $а к-$ 'белый', 'чистый’, 'седой’, 'сивый’; ‘белок' (глаза), ‘прекрасный’ ... (Севортян, 1974: 116-117; Татаринцев, 2000: 83). В данном 
примере слово ак использовано в переносном значении: «белый (чистый) брод, т. е. брод, через который можно перейти без препятствий» (Ондар, 2007: 92). У тувинцев, как и у других тюркских народов (Бисенбаев, 2007), белый цвет является символом светлого, доброго и благоприятного; кежиг [кэбжиг] - 'брод’, 'переправа' (Тувинско-русский словарь, 1968: 235), дериват кеш-/ кежер - ‘переходит’, ‘переплавляться’ (Толковый словарь ... , 2011: 206), смотри общетюркское кез- - 'проходить' (Севортян, 1997: 21).

В конце лета в Ак-Кежиг перекочевывают животноводы из родоплеменных групп сат, монгуш и донгак.

\section{3. Топонимы, связанные с природными особенностями местности}

Адырган / Адарган [адырган] - буквально «отделить, разъединить», т. е. 'отделенный, разъединенный': это местность и минеральный источник (Ондар, 2007: 76), а также летняя стоянка чайлаг вблизи минерального источника, стоящей отдаленно. Адыр - 'отцеплять', 'отделять, разъединять' и подобное (Тувинско-русский словарь, 1968: 38), общетюркское слово, смотри айыр -

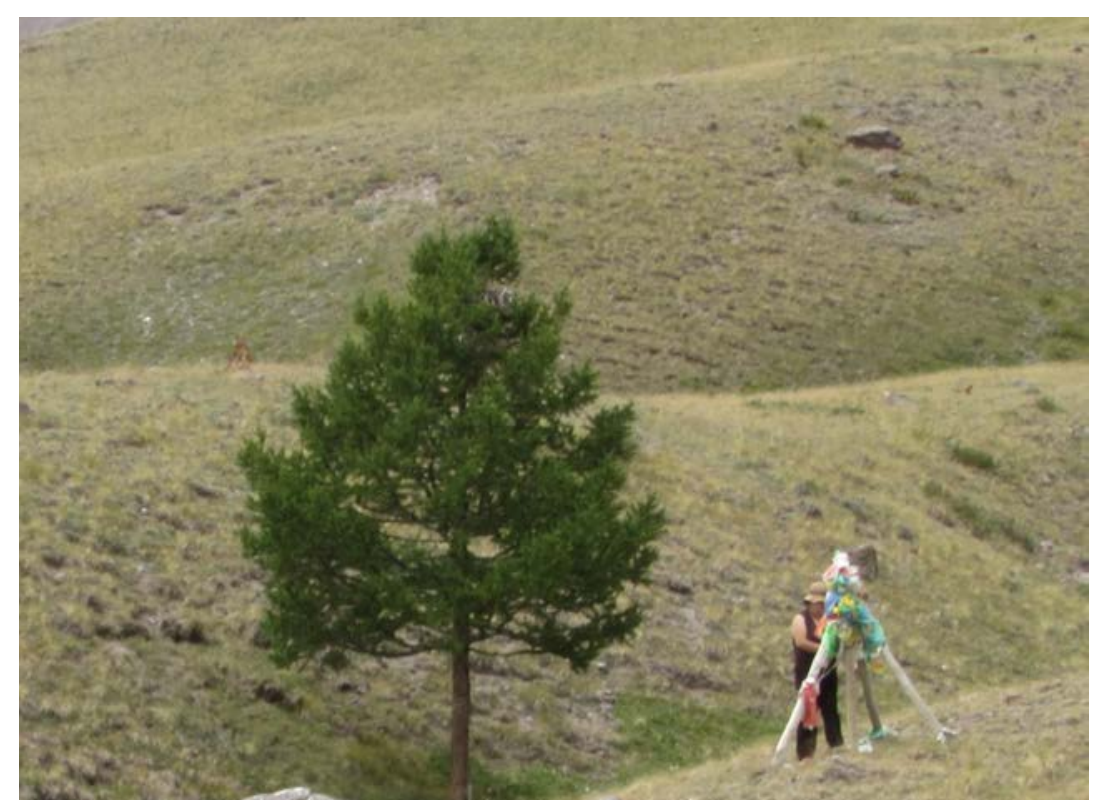

Фото 2. Священная лиственница рода донгаков на летней стоянке Адырган. Фото автора, 2015 г.

Photo 2. The sacred larch tree of the house Dongak at the summer campsite at Odyrgan. Photo by the author, 2015. 'отделять' и подобное (Севортян, 1974: 114; Татаринцев, 2000: 60).

В Адыргане есть священная лиственница бай дыт рода донгаков, которую они освящают в середине лета.

Думчукужу - буквально «нос конец», т. е. 'конец острого выступа горы': название местности, не зафиксированного в «Т о п о н и м и ч е с к о словаре», собственно тувинский топоним, выраженный словосочетанием, состоящим из общетюркских основ: думчук 'нос / носовой', 'клюв, хобот’, 'уступ (горы)' (Тувинско-русский словарь, 1968: 183), в географии передает значение 'конец вытянутой части; уступ горы, холма, скалы’ (Толковый словарь ..., 2003: 512), общетюркское слово, смотри *tumšuk - 'клюв, нос, хобот' (Сравнительно-историческая грамматика ..., 2001: 216; Татаринцев, 2002: 269), ужу - ‘конец’, смотри общетюркское у:ч - ‘конец’, 'верх, верхушка’ и подобное (Севортян, 1974: 611). 
Арыг-Бажы [арыгбаъжы] - букв. «леса начало», т. е. 'начало леса': название местности - зимней стоянки (кыштаг), урочища (чыраалыг чер), населённого пункта (чер) в Овюрском и Улуг-Хемском районах (Ондар, 2007: 127). Собственно тувинское сложное слово из общетюрких основ: арыг - 'пойменный лес', ‘лесной’ (Тувинско-русский словарь, 1968: 71), по мнению Э. В. Севортяна, в тюркских языках центральным является значение 'текущая/ проточная вода', а значение 'лес' распространено в тюркских языках Сибири и в старейших памятниках тюркской письменности (Севортян, 1974: 188-189); бажы баш в значении 'начало', как уже рассматривали, является общетюркским (Севортян, 1978: 85).

Арыг-Бажы находится на территории местности Бора-Шай, поэтому говорят «Бора-Шайның Арыг-Бажы» - «Арыг-Бажы из Бора-Шая» и живут тувинцы из рода тулуш.

Бош-Даг [поъштаг] - буквально «шаткая гора»: название летней стоянки в Овюрском районе. Одноимённые топонимы встречаются в Улуг-Хемском районе как название горы и системы реки Иштии-Хем (Ондар, 2007: 171). Собственно тувинское сложное слово из общетюркских основ: бош [повш]'незакреплённый, непривязанный', 'неустойчивый, шаткий' (Тувинскорусский словарь, 1968: 116), 'свободный, незанятый’ (Толковый словарь ... , 2003: 296), смотри общетюркское бош / boš - ‘пустой, незанятый, свободный’ и подобное (Севортян, 1978: 203); даг - 'гора', 'относящийся к разработке недр, горный’ (Тувинско-русский словарь, 1968: 140; Толковый словарь ... , 2003: 368), смотри общетюркское да:ғ - 'гора / горы' и подобное (Севортян, 1980: 117-118; Татаринцев, 2002: 35).

мугур [муъгур] - буквально «тупой»: реки Бай-Тайгинском, Монгун-Тайгинском, Овюрском районах, населенный пункт Дзун-Хемчикском районе (Ондар, 2007: 304), а также летняя стоянка чайлаг у небольшой тупиковой реки в Овюре: мугур - 'тупой', 'ровно, точно' (мугур үш шак - «ровно три часа») (Тувинско-русский словарь, 1968: 302), монголизм, см. монг. мухар - 'куцый', 'тупой', 'комолый’ и подобное (Большой академический ..., 2001b: 361).

$\boldsymbol{\theta в} \boldsymbol{p}$ - южный район Тувы с центром Хандагайты (Ондар, 2007: 329), монголизм, смотри монгольское өвөр - 'южный склон, южная сторона (горы)', 'южный’ (Большой академический ..., 2001с: 3).

Саглы [саглы] - название реки, степи, долины и села в Овюре. Б. К. Ондар этимологию саглы считает дискуссионной: 1) от монгольского сагилдаг, в ботанике означает ‘ирис, мечевидный касатик’, сравни с тувинским сагылдак;

\footnotetext{
${ }^{1}$ В словах специфический фарингализованный гласный при транскрипции обозначается знаком «ъ»: артикуляции данного звука «мускулы в стенках глотки, в том числе и мускулы корня языка, сближаются, отделяя собой нижнюю часть глотки в виде особого резонатора, а гортань отходит вниз, увеличивая тем объем нижнего глоточного резонатора» (Кунаа, 1957: 23).
} 


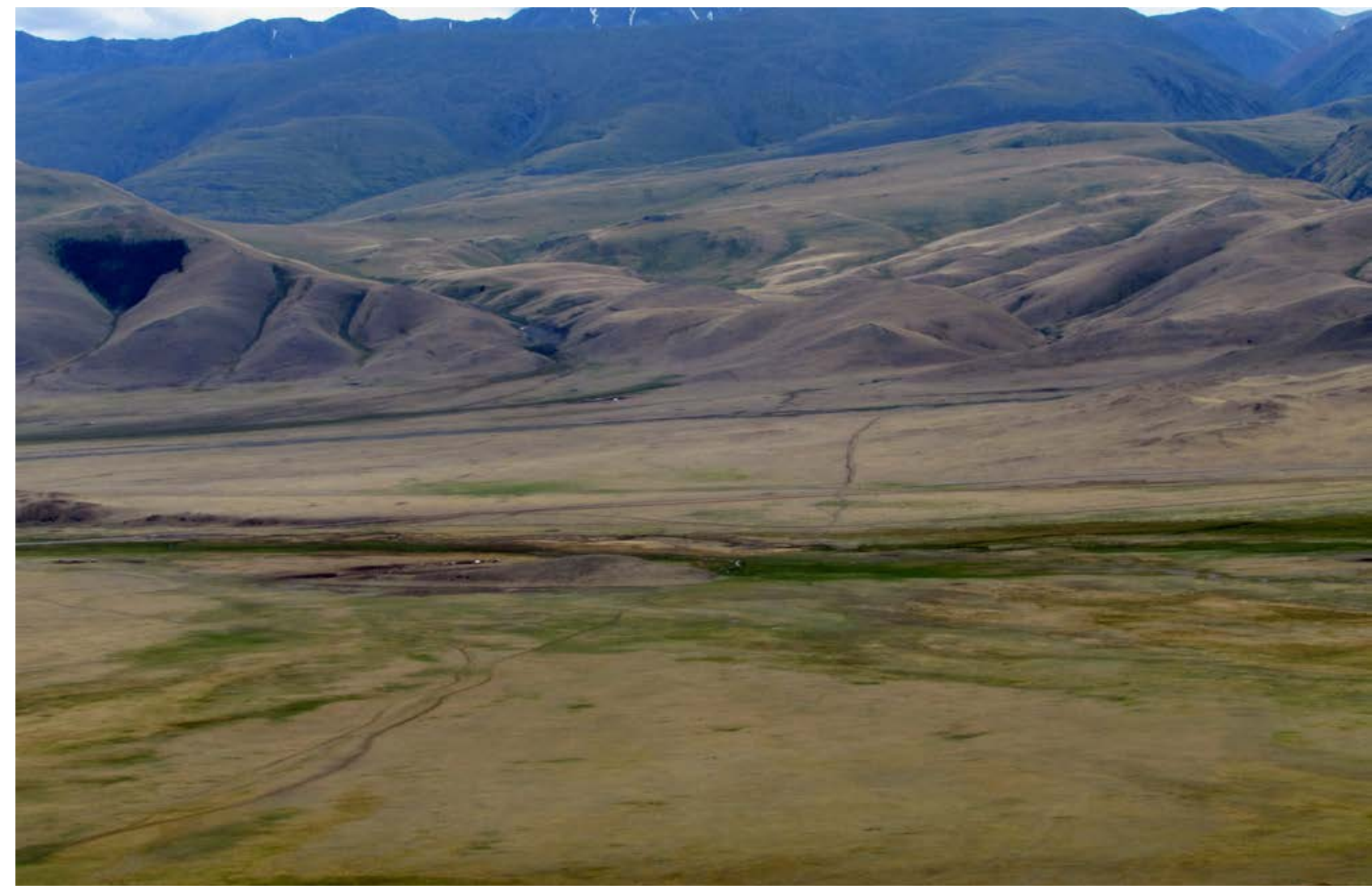

Фото 3. Летние стоянки в Саглы-Бажы. Фото автора, 2015 г.

Photo 3. Summer campsites at Sagly-Bazhy. Photo by the author, 2015.

2) от тувинского сагыл, монгольское цахил - 'религиозный обет, постриг'; 3) от личного имени Саглы (Ондар, 2007: 342).

По нашему предположению, Саглы, скорее всего, связано с монгольским салхи(н) - 'ветер', 'ветряной, ветровой; подветренный, подвергающийся действию ветра' (Большой академический ..., 2001с: 79-80): река Саглы берёт начало на территории Тувы, а затем продолжает свое русло в Монголии и называется Салхини-Гол - буквально «ветряная река», т. е. данный топоним отражает природные особенности данной местности. Нашу версию подтвердили и жители села Caглы, которые данное название связывают с трепетанием слабого ветерка салгын саглаңнаар - буквально «ветерок трепещет»: местность ветреная, постоянно дует слабый ветерок.

Лексема салгын зафиксирована во многих тюркских языках в форме салқын 'прохладный', 'холодный, студёный', 'прохладный ветер'. Но, тем не менее, ее относят к монгольскому заимствованию: «... для тюркских языков Сибири (особенно якутского) семантика салқын говорит за монгольский источник» (Этимологический словарь ..., 2003: 182-183).

Территория Саглы прославилась древнетюркскими курганами с изваяниями и балбалами, исследованными археологической экспедицией А. Д. Грача (Грач, 1980: 110-120). Здесь живут представители родоплеменных групп ооржак, 
саая (халыынские саая), кара-сал, куулар (История Тувы, 2001: 70) и монгуш (саглынские монгуши).

Саглы-Бажы [саглыбаъжы] - буквально «Саглы вершина», т. е. 'вершина Саглы’ или 'начало Саглы’ : название летней стоянки чайлаг на территории села Саглы, которое не зафиксировано в словаре Б. К. Ондар; собственно тувинское сложное слово. Саглы - смотри выше. Бажы с аффиксом принадлежности выражен общетюрким словом со значениями 'голова', 'глава', 'вершина, верхушка', 'начало', 'главный’ (Севортян, 1978: 85-88).

Саглы-Бажы - летняя стоянка животноводов из рода ооржак.

4. Топонимы, связанные с животным миром Овюра

Торгалыг [т'оргалыг] ${ }^{1}$ - буквально «имеющий дятла», название реки, населенного пункта, села в Овюрском районе, название минерального источника (аржаан), левый приток реки Улуг-Хем в Улуг-Хемском районе (Ондар, 2007: 393). Дериват Торгалыга торга 'дятел' + аффикс -лыг, обозначающий предмет обладания, общетюркское слово (Сравнительно-историческая грамматика ..., 2001: 175).

В 1990 г. Торгалыг переименовали в Дус-Даг (смотри ниже), где живут тувинцы из рода донгак, поэтому в настоящее время Торгалыг является только названием реки и минерального источника.

Хaйдагайты [хандагайты] - районный центр Овюра, название реки, которая впадает в озеро Успа-Хөл (Убсу-Нур), монголизм, смотри монгольское хандгай - ‘лось, сохатый’ (Большой академический ..., 2002: 40) + аффикс -ты 'с лосями' (Ондар, 2007: 444). Старожилы вспоминали, что раньше, когда вдоль реки Хандагайты стояли летние стоянки (чайлаглар) аратов, на берегах реки водились лоси, поэтому местность названа так. В районном центре Хандагайты в основном живут тувинцы из рода монгуш.

Сыынныг-Kaъm [сы:ныгкаът] - буквально «маралий хребет»; название горы, реки в Дзун-Хемчикском районе (Ондар, 2007: 373), летняя стоянка в Овюре. Собственно тувинское сложное слово из общетюрких основ: cыblнныг 'маралий’, дериват сыын - 'марал' (Тувинско-русский словарь, 1968: 399), смотри тюркское sygun - 'олень-марал’ (Сравнительно-историческая грамматика ..., 2001: 152); кабт - 'ряд; слой, пласт', ‘этаж', 'солнечная сторона отрога горного хребта (не покрытая лесом)’ (Тувинско-русский словарь, 1968: 233), смотри тюркское қат - ‘слой', 'ряд’, ‘этаж’ и подобное (Севортян 1997: 335-336).

5. Топонимы, связанные с этнонимами Овюра

Калга-Кежии [каългакэжи:] - букв. «калга брод», т. е. 'переправа или брод халхи’: название летней стоянки; собственно тувинское сложное слово: калга

${ }^{1}$ В начале слова «сильная фонема, приносящаяся всегда глухо и с относительно заметным придыханием» (Сравнительно-историческая грамматика ..., 2002: 624). 
[каблга] монгольский этноним халха, см. монгольское халх - 'халха, халхасец (монгольское племя в Северной Монголии)' (Большой академический... , 2002: 29); кежии кежиг - ‘брод’, 'переправа' (Тувинско-русский словарь, 1968: 235), дериват кеш-/ кежер - 'переходить', ‘переезжать', 'переправляться’ (Толковый словарь ..., 2011: 106), смотри общетюркское кез- - 'проходить' (Этимологический словарь ..., 1997: 21).

Раньше в данной местности жили халхи, и брод был построен ими.

Моолдуг-Хем [мо:лдугхэм] - буквально «с монголами река»: река (Ондар 2007: 300) и название летней стоянки, собственно тувинское сложное слово: моолдуг - 'с монголами', дериват моол - 'монгол, монголка' (Тувинско-русский словарь, 1968: 298), монголизм, смотри монгол - 'Монголия’, 'монгол, монголка' (Большой академический ... , 2001b: 337); хем - 'река, речной’ (Тувинскорусский словарь, 1968: 473), древнетюркское слово, смотри кем - 'река' (Древнетюркский словарь, 1969: 297).

Моолдуг-Хем - правый приток реки Бора-Шай, куда перекочёвывают монгуши, куулары, саты и тулуши. По сведениям наших информаторов, раньше с коренными жителями данной местности с монгушами жили и монголы.

Тээли бажы [тэ:либаъжы] - буквально «тээли вершина», т. е. вершина Тээли: летняя стоянка у горы Тээли в Овюре, недавно там построили субурган (буддийскую ступу); собственно тувинское сложное слово: Б. К. Ондар, предполагает, что слово тээли восходит к этнониму древних тюрок деле/ теле / телес (Ондар, 2007: 400), а Ш. Ч. Сат считает монголизмом со значением ‘небольшое степное место' (Сат, 1987: 36); общетюркское бажы баш - ‘голова', ‘начало’ и подобное (Севортян, 1978: 85).

В Тээли-Бажы живут тувинцы из рода тээли-донгак.

Чөвүрээлиг-Тээли буквально «с корой (дерева) тээли» - название местности (Ондар 2007: 496), где растут хвойные деревья; собственно тувинское сложное слово: чөвұрээлиг - ‘с корой’, дериват чөвүрээ - ‘кора (дерева)' (Тувинскорусский словарь, 1968: 542), встречается в тюркских языках Сибири, смотри тофаларское чөъпрәә - ‘кора хвойных деревьев и тополя’, алтайское - чобра / чобырга - ‘кора лиственницы’, хакасское собыра - ‘сухая кора тополя’ (Рассадин, 1995: 91). Тээли - смотри выше.

В Чөвүрээлиг-Тээли живут тувинцы из рода тумат.

\section{6. Топонимы, связанные с полезными ископаемыми}

Дус-Даг [тустаг] - буквально «соль-гора», название горы (даг) в Овюре (Ондар, 2007: 205). Гора названа так из-за того, что она с давних времён является местом добычи каменной соли. В настоящее время Дус-Дагом называется и село, которое находится в 14 км от горы с каменной солью; собственно тувинское сложное слово из общетюркских основ: дус - 'соль' (Тувинско-русский словарь, 


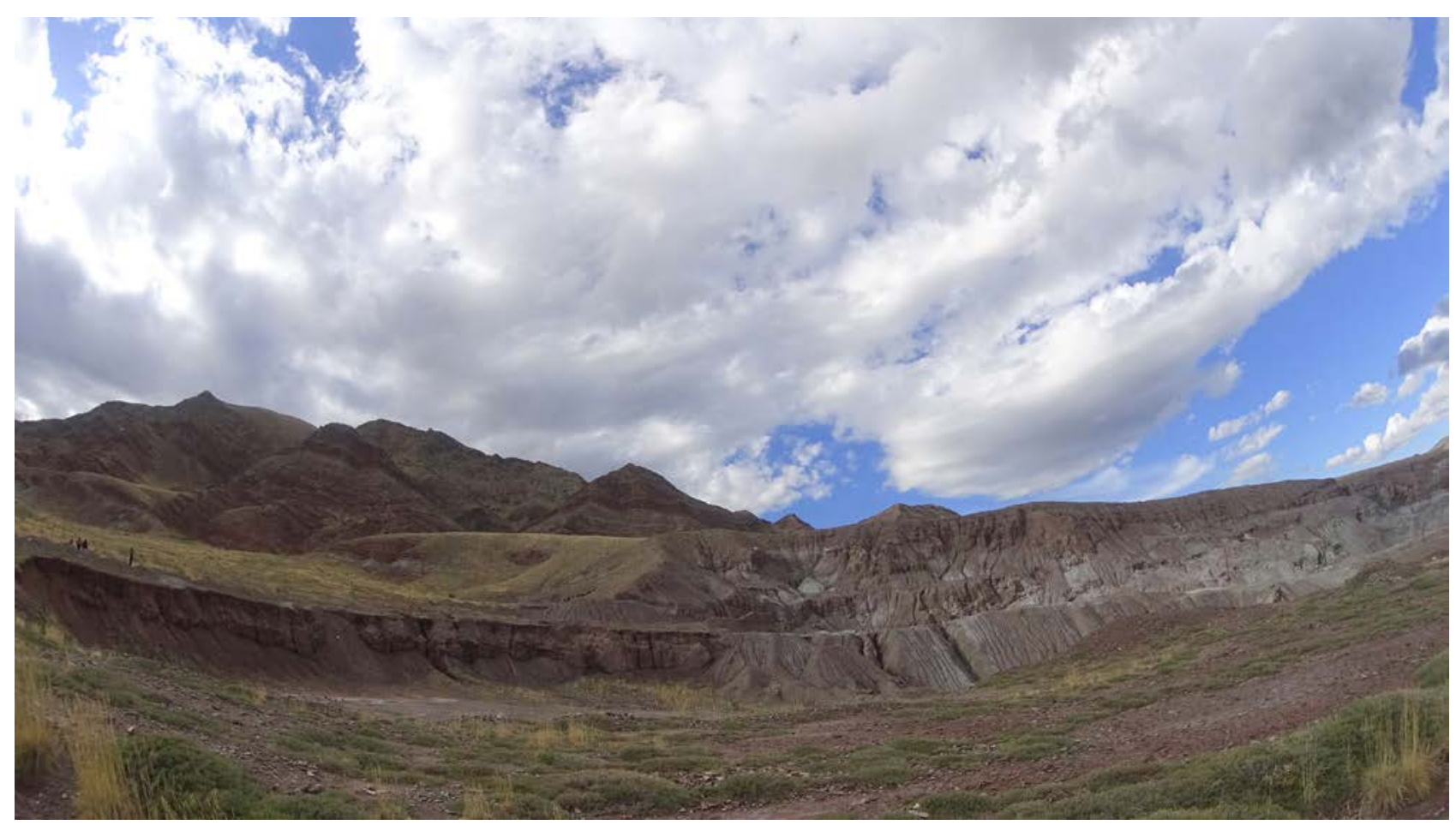

Фото 4. Гора Дус-Даг. Фото автора, 2017 г.

Photo 4. Dus Dag mountain, photo by the author, 2017.

1968: 184), смотри дус - 'соль' (Севортян, 1980: 288; Татаринцев, 2002: 277); общетюркское даг - 'гора' (Севортян 1980: 118; Татаринцев, 2002: 35).

В Дус-Даге в основном живут тувинцы из рода донгак.

7. Топонимы, связанные с событиями из жизни овюрцев

Кара-Туруг [карат'уруг] - буквально «черный утёс», название утёса (туруг) и летней стоянки в Овюрском районе. В «Топонимическом словаре Тувы»

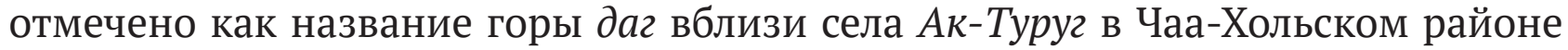
(Ондар, 2007: 242), собственно тувинское сложное имя из общетюркого кара ‘чёрный, тёмный' (Этимологический словарь ..., 1997: 286); туруг - 'отвесная скала', 'утёс' (Тувинско-русский словарь, 1968: 425), отмечено у Махмуда Кашгари как 'убежище', ‘прибежище', ‘логовище' (в горах) (Древнетюркский словарь, 1969: 588).

Согласно легенде, в старину с утёса спрыгнула девушка, которую насильно выдали замуж за нелюбимого. С тех пор эту местность называют Кара-Туруг, где кара использовано в переносном значении 'мрачный, тяжёлый' (Тувинскорусский словарь, 1968: 226) или 'плохой, злой’ (Толковый словарь ..., 2003: 66).

Кара-Туруг издавна считается малой родиной овюрцев-донгаков, в настоящее время в летнее время сюда перекочёвывают и монгуши.

Солчур [солчур] - букв. «обмениваться», название местности, источника, горы и села (Ондар, 2007: 360); солчур / солуш- от солу- - 'обмениваться' (Тувинско- 


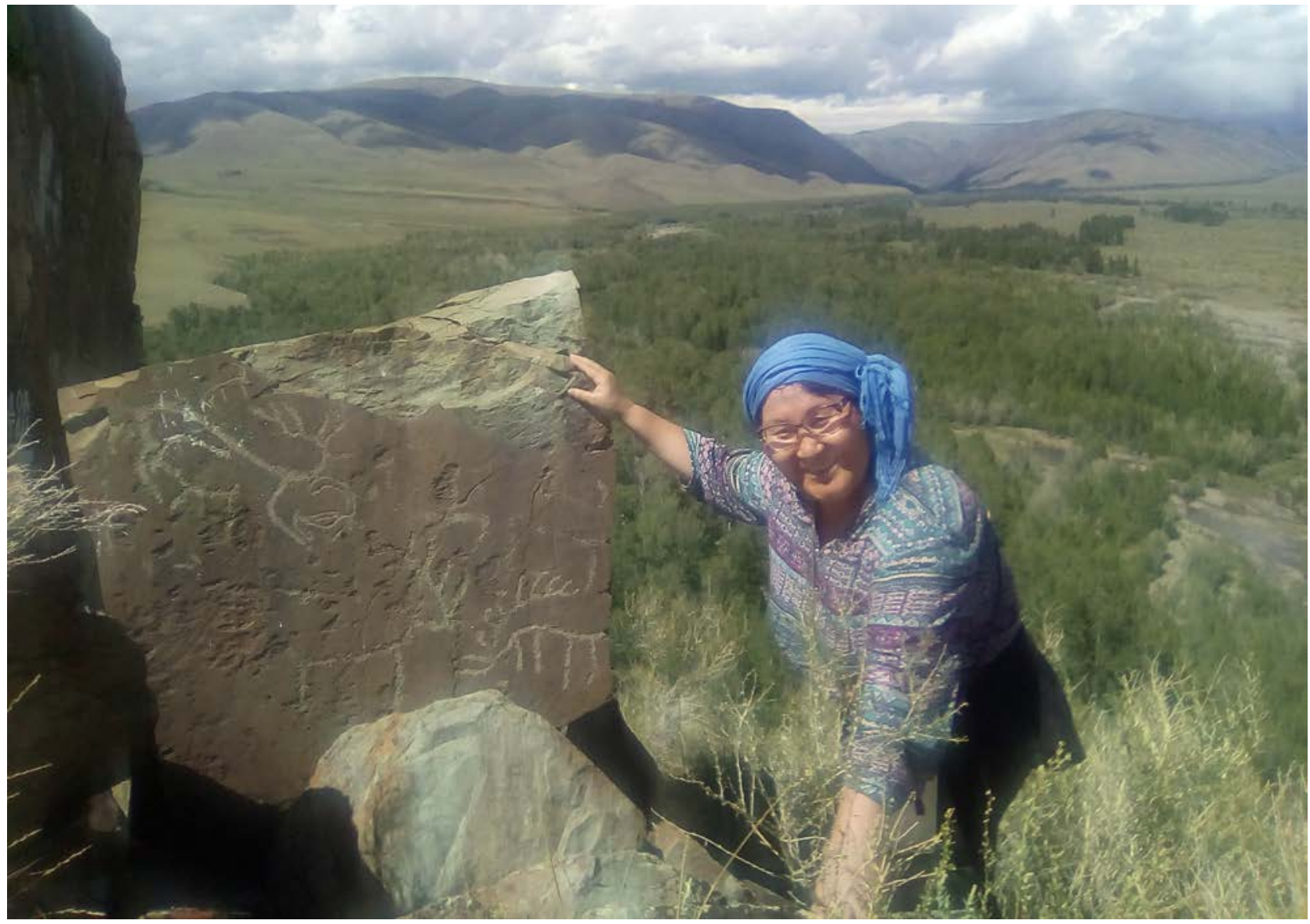

Фото 5. Автор у камней с петроглифами на Кара-Туруге. Фото Елены Айыжы. 20172. Photo 5. The author holding petroglyphed stones at Kara-Turug, photo by Elena Ayuzhy, 2017.

русский словарь, 1968: 381), 'сменяться, сменять друг друга' (Толковый словарь ..., 2011: 706), монголизм, смотри солих - 'сменить, заменить', 'менять, обменивать' и подобное, солицох - 'обмениваться, взаимно обменяться' (Большой академический ... , 2001: 109). Ш. Ч. Сат предположил, что солчур монголизм со значением 'не парный, один, отдельный' (Сат, 1987: 36).

Название местности связано со значением 'обмениваться' по следующей причине: жители села до сих пор помнят, как у подножия горы Солчур возле пограничного поста тувинцы и монголы в советские времена обменивались товарами.

В селе Солчур живут тувинцы из рода монгуш, кара-монгуш.

\section{Заключение}

Таким образом, топонимическое своеобразие территории Овюрского района заключается в том, что в нем отмечены две принципиально разные тенденции присвоения географических имен: это, во-первых, кочевая (названия стоянок животноводов в зависимости от времен года: чайлаг - ‘летняя стоянка', күзег - 
'осенняя стоянка', кыштаг - 'зимняя стоянка', чазаг - 'весенняя стоянка') и, во-вторых, оседлая (названия сел, деревень). Раньше у каждой родоплеменной группы местности (тумат, тулуш, донгак, монгуш, куулар, сат, ооржак, саая, кыргыс) были свои стоянки, т. е. топонимы были тесно связаны с каким-то родом. В настоящее время многие из них оставлены, и люди не помнят, какому роду принадлежала территория. Места стали общими и в этом немаловажную роль сыграло территориальное перемещение людей не только внутри района, но и по всей Туве.

Наименования сел и стоянок животноводов связаны с названиями рек, гор и других географических объектов, вблизи которых они появились, т. е. они названы по имени последних.

В структурном и этимологическом отношениях значительную часть топонимов Овюра составляют собственно тувинские сложные слова, компоненты которых выражены общетюркскими (Ак-Чыраа, Арыг-Бажы, Адыр-Тал, Кара-Дыт, Хаактыг-Арт, Сарыг-Хөл, Сарыг-Хая, Ак-Кежиг, Думчук-Ужу, БошДаг, Сыынныг-Кавт, Дус-Даг, Кара-Туруг и т.д.), тюрко-монгольскими или монголо-тюркскими (Чаа-Суур, Шокар-Хараган, Саглы-Бажы, Калга-Кежии, Моолдуг-Хем и т.д.), монголо-китайскими (Бора-Шай) словами. Простые топонимы выражены общетюрскими словами (Адырган, Торгалыг и т. д.) и монгольскими заимствованиями (Мугур, Саглы, Хандагайты, Солчур и т. д.), которые полностью освоены. Значение доставшееся топониму в наследие от нарицательного является существенным для местного населения, но, тем не менее, материально не всегда совпадает со словом, поэтому у некоторых топонимов иная природа и семантика (Кара-Туруг, Саглы, Кара-Дыт, БораШай, Сарыг-Хөл и т.д.). Некоторые топонимы выражены не словами, а словосочетаниями, например, Думчук ужу.

Наличие в составе топонимов Овюра следующих формантов: гидронимических (хем - 'река', хөл - 'озеро', кежиг - 'переправа'); фитонимических (хаак 'мелкий тальник', дыт - 'лиственница', хараган - 'караганник', тал - 'ива'); оронимических (даг - 'гора', туруг - 'утес', apm - 'перевал', кавт - 'солнечная сторона отрога горного хребта'), а также дримонимических (арыг - 'река', чыраа - 'ивняк, заросли ивы') и т. д. указывают на природно-географические особенности местности.

Анализ показывает, что специфические особенности топонимов Овюра свойственны не только для данной территории, но и для топонимов всей Тувы, но, тем не менее, надеемся, что материал данной статьи будут полезен при изучении географических, этнокультурных и историко-культурных апеллятивов в топонимии; проблем разнонаписания названий одних и тех же географических объектов, а также будут использованы при исследовании ареала распространения странствующих тюркских географических терминов и названий. И в итоге, можно определить какие тюркские топонимы на 
современном этапе читаются на географической карте обширной территории Центральной, Средней и Внутренней Азии, Урала и Европейской части России.

\section{СПИСОК ЛИТЕРАТУРЫ}

Бавуу-Сюрюн, М. В. (2005) Структура топонимов монгольского происхождения на территории Тувы // Тыва дылдың лексиказынга факультативтер / научн. ред. Е. Б. Салзынмаа. Кызыл : Аныяк. 116 с. С. 111-115.

Большой академический монгольско-русский словарь (2001a) / отв. ред. Г. Ц. Пюрбеев. М. : ACADEMIA. Т. І. Ф-Г. 488 с.

Большой академический монгольско-русский словарь (2001b) / отв. ред. Г. Ц. Пюрбеев. М. : ACADEMIA. Т. II. Д-О. 514 с.

Большой академический монгольско-русский словарь (2001с) / отв. ред. Г. Ц. Пюрбеев. М. : ACADEMIA. Т. III. Ө-Ф. 440 с.

Большой академический монгольско-русский словарь (2002) / отв. ред. Г. Ц. Пюрбеев. М. : ACADEMIA. T. IV. X-Я. 510 с.

Бисенбаев, А. К. (2007) Мифы древних тюрков. Алматы : Ан-Арыс. 136 с.

Грач, А. Д. (1980) Древние кочевники в центре Азии. М. : Наука. 256 с.

Грумм-Гржимайло, Г. Е. (2007) Западная Монголия и Урянхайский край. Антропологический и этнографический очерк этих стран // Урянхай. Тыва дептер. Антология научной и просветительской мысли о древней тувинской земле и ее насельниках, об Урянхае - Танну-Туве, урянхайцах - тувинцах, о древностях Тувы: в 7 т. / сост. С. К. Шойгу. М. : Слово. Т. 2. Племена Саяно-Алтая. Урянхайцы (IV в. - начало XX в.). 664 с. С. 496-638.

Древнетюркский словарь (1969) / ред.: В. М. Наделяев, Д. М. Насилов, Э. Р. Тенишев, А. М. Щербак. Л. : Наука. 676 с.

История Тувы (2001).2-е изд., перераб. и доп./ под общ. ред. С. И. Вайнштейна, М. Х. Маннай-оола. Новосибирск : Наука. Т. 1.367 с.

Каррутерс, Д. (2007) Неведомая Монголия. Урянхайский край. Т. 1. / пер. с англ. Н. В. Турчанинова. Петроград //Урянхай. Тыва дептер. Антология научной и просветительской мысли о древней тувинской земле и ее насельниках, об Урянхае - Танну-Туве, урянхайцах - тувинцах, о древностях Тувы: в 7 т. / сост. С. К. Шойгу. М. : Слово. Т. 4. Урянхайский край: перекресток мнений (конец XIX - начало XX вв.). 552 с. С. 10-260.

Катанов, Н. Ф. (1903) Опытъ изслъдованія урянхайскаго языка, съ указаніемъ главнъйшихъ родственныхъ отношеній его къ другимъ языкамъ тюркскаго корня. Казань: Типо-литографія Императорскаго Казанскаго Университета. $1600 \mathrm{c}$. 
Кон, Ф. Я. (1934) За пятьдесят лет : Собрание сочинений : в 3 т. М. : Изд-во Всес. о-ва политкаторжан и ссыльно-поселенцев ; тип. Профиздата. Т. 3: Экспедиция в Сойотию. 293 с.

Кормушин, И. В. (1997) Тюркские енисейские эпитафии. Тексты и исследования / отв. редактор Э. Р. Тенишев. М. : Наука. 303 с.

Кормушин, И. В. (2008) Тюркские енисейские эпитафии. Грамматика, текстология / отв. редактор Д. М. Насилов. М. : Наука. 342 с.

Кунаа, А. Ч. (1957) Звуковая система современного тувинского языка / ред. Ш. Ч. Сат. Кызыл : Типография управления культуры. 56 с.

Маннай-оол, М. Х. (1961) Археологические исследования в Овюрском районе в 1960 г. // Ученые записки ТНИИЯЛИ. Вып. ІХ. / ред. коллегия: Сердобов Н. А. и др. Кызыл : Тип-я Управления культуры. 283 с. С. 222-229.

Молчанова, О. А., Мурзаев Э. М. (2005) Тюркские географические названия // Алтайское языкознание и восточная филология: Памяти Э. Р. Тенишева / ред. колл.: К. Н. Бичелдей и др. М. : Восточная литература РАН. 520 с. С. 240-248.

Ондар, Б. К. (1995) Краткий словарь гидронимов Тувы / под ред. И. В. Кормушина. Кызыл : Тувинское книжное издательство. 48 с.

Ондар, Б. К. (1999) С. А. Сарыг-оолдуң чогаалдарында топонимнер [Топонимы в произведениях С. А. Сарыг-оола] // Юбилеи писателей. Материалы конференций, посвященных юбилеям писателей / гл. редактор С. Х. Хурен-оол. Кызыл : РИО ТувГУ. 118 с. С. 47-50.

Ондар, Б. К. (2000) Монголизмы в топонимии Тувы // Становление и развитие науки в Туве. Материалы Международной конференции, посвященной к 70-летию тувинской письменности 12-14 сентября 2000 г. : в 2 частях / редколлегия: Х. Д-Н. Ооржак и др. Кызыл : РИО ТувГУ. Ч. 1. 140 с. С. 56-57.

Ондар, Б. К. (2001) Некоторые параллели в топонимии Тывы и Хакасии // Актуальные проблемы сохранения и развития языков, культур и истории Саяно-Алтая Материалы международной научной конференции, посвященной 280-летию дешифровки древнетюркской писменности / под ред. С. П. Ултургашева, Л. И. Чебодаевой. Абакан : Изд-во ХГУ им. Н. Ф. Катанова. 262 с. С. $120-124$.

Ондар, Б. К. (2003) Табу и эвфемизмы в тывинской топонимии // Вестник Хакасского государственного университета им. Н. Ф. Катанова. Серия 5. Филология: Языкознание. Вып. 5; Серия 6. Филология: Литературоведение. Вып. 2. С. 38-41.

Ондар, Б. К. (2004) Топонимический словарь Тувы. Абакан : Изд-во ХГУ им. Н. Ф. Катанова. 254 с. 
Ондар, Б.К.(2005) Источники по тувинской топонимике //Гуманитарная наука Тувы на стыке веков: история, проблемы и перспективы развития : доклады научно-практической конференции, посвященной 75-летию тувинской письменности и 60-летию ТНИИЯЛИ - ТИГИ). 13-14 октября 2005 года. Кызыл : Тип. КЦО Аныяк. 136 с. С. 65-70.

Ондар, Б. К. (2006) О некоторых названиях аржаанов Тыва (сравнительносопоставительный анализ) // Эртем бижиктери. 1-ги үндүрүлгези / Ученые записки: Ежегодник кафедры тувинского и общего языкознания ТывГУ. Вып. 1. Кызыл: ТывГУ. 170 с. С. 51-59.

Ондар, Б. К. (2007) Топонимический словарь Тувы. 2-е изд. Кызыл : Тувинское книжное издательство. 550 с.

Ондар, Б. К. (2008а) Тувинская топонимия. Сопоставительный анализ топонимии Тувы с топонимией Южной Сибири и других тюркоязычных территорий. Кызыл : Тув. кн. изд-во. 304 с.

Ондар, Б. К. (2008b) Тувинская топонимика: проблемы, поиски, решения. Проблемы преподавания русского языка в вузе и в школе. Кызыл : РИО ТувГУ. 233 c.

Потанин, Г. Н. (2007) Очерки Северо-Западной Монголии. Результаты путешествия, исполненного в 1876-1877 годах по поручению Императорского Русского Географического Общества. Выпуск II. Материалы этнографические. СПб // Урянхай. Тыва дептер. Антология научной и просветительской мысли о древней тувинской земле и ее насельниках, об Урянхае - Танну-Туве, урянхайцах - тувинцах, о древностях Тувы: в 7 т. / сост. С. К. Шойгу. М. : Слово. T. 2. Племена Саяно-Алтая. Урянхайцы (IV в. - начало XX в.). 664 с. С. 496-638.

Потанина, А. В. (2003) Из путешествий по Восточной Сибири, Монголии, Тибету и Китаю. Москва. Из странствий по Урянхайской земле // Традиционная культура тувинцев глазами иностранцев (конец XIX - начало ХХ вв.)/подготовка текстов, предисловие и комментарии А. К. Кужугет. Кызыл : Тувинское книжное издательство. 224 с. С. 29-38.

Рассадин, В. И. (1971) Фонетика и лексика тофаларского языка / отв. редактор Ц. Б. Цыдендамбаев. Улан-Удэ : Бурятское кн. изд-во. 252 с.

Рассадин, В. И. (1995) Тофаларско-русский, русско-тофаларский словарь / отв. редактор И. Д. Бураев. Иркутск : Восточно-Сибирское кн. изд-во. 288 с.

Родевич, Вс. (2003) Урянхайский край и его обитатели. Санкт-Петербург // Традиционная культура тувинцев глазами иностранцев (конец XIX - начало XX вв.) / подготовка текстов, предисловие и комментарии А. К. Кужугет. Кызыл : Тувинское книжное издательство. 224 с. С. 136-141.

Сат, Ш. Ч. (1969) Заметки по топонимии Тувы // Материалы конференции «Этногенез народов Северной Азии» / отв. ред. Е. И. Убрятова. Новосибирск : б/и. Вып. 1.247 с. С. 232-234. 
Сат, Ш. Ч. (1987) Тыва диалектология / ред. Е. Б. Салзынмаа. Кызыл : ТНҮЧ. 104 с. (На тув. яз.).

Севортян, Э. В. (1974) Этимологический словарь тюркских языков: общетюркские и межтюркские основы на гласные / ред. Р. М. Залесковская. М. : Наука. 768 с.

Севортян, Э. В. (1978) Этимологический словарь тюркских языков: общетюркские и межтюркские основы на букву “Б” / отв. ред. Н. З. Гаджиева. М. : Наука. 352 с.

Севортян, Э. В. (1980) Этимологический словарь тюркских языков: общетюркские и межтюркские основы на буквы “В”, “Г”, “Д” / отв. ред. Н. З. Гаджиева. М. : Наука. 396 с.

Сравнительно-историческая грамматика тюркских языков. Лексика (2001) / отв. ред. Э. Р. Тенишев. М. : Наука. 824 с.

Сравнительно-историческая грамматика тюркских языков. Региональные реконструкции (2002) / отв. ред. Э. Р. Тенишев. М. : Наука. 767 с.

Сувандии, Н. Д. (2004) Тувинская антропонимия: автореф. дисс. ... канд. филол. н. М. ; Кызыл. 21 с.

Сувандии, Н. Д. (2013) Современное состояние изучения ономастики тувинского языка // Мир науки, культуры, образования. Вып. 6 (43). С. 362-364.

Сувандии, Н. Д. (2015) Становление фамилий и отчеств в тувинском языке // Филологические науки. Вопросы теории и практики. № 12 (54). Ч. І. С. 171-173.

Татаринцев, Б. И. (1973) Об особенностях топонимии Северо-Восточной Тувы //Происхождение аборигенов Сибири и их языков: Материалы всесоюзной конференции 14-16 июня 1973 г. / ред. коллегия: Э. Г. Беккер [и др.]. Томск : Изд-во Томского университета. 235 с. С. 142-144.

Татаринцев, Б. И. (1977а) Местные географические термины Северо-Восточной Тувы // Советская тюркология / гл. ред. М. Ш. Ширалиев. Баку : Тип-я им. 26-ти бакинских комиссаров. Вып. 5. 112 с. С. 18-26.

Татаринцев, Б. И. (1977b) О топонимии бассейна р. Каа-Хем // Тувинский язык и литература в послеоктябрьский период / ред. коллегия: Д. А. Монгуш (отв. ред.) [и др.]. Кызыл : Тип-ия управления по делам издательств, полиграфии и книжной торговли Совета Министров Тув. АССР. 192 с. С. 88-98.

Татаринцев, Б. И. (1993) О некоторых древних топонимах тюркского происхождения на территории Тувы // Вопросы тувинского языкознания / редакторы Д. А. Монгуш, Б. И. Татаринцев. Кызыл : Новости Тувы. 128 с. С. 105-113.

Толковый словарь тувинского языка (2003) / ред. Д. А. Монгуш. Новосибирск : Наука. Т. І. А-Й. 600 с.

Толковый словарь тувинского языка (2011) / ред. Д. А. Монгуш. Новосибирск : Наука. Т. II. K-C 800 с. 
Тувинско-русский словарь (1968) : 22000 слов / ред. Э. Р. Тенишев. М. : Советская энциклопедия. 648 с.

Татаринцев, Б. И. (2000) Этимологический словарь тувинского языка. Новосибирск : Наука. Т. І. А-Б. 341 с.

Татаринцев, Б. И. (2002) Этимологический словарь тувинского языка. Новосибирск : Наука. Т. ІІ. Д-Й. 388 с.

Этимологический словарь тюркских языков: общетюркские и межтюркские основы на букву “К”, “Қ” (1997) / отв. ред. Г. Ф. Благова. М. : Языки русской культуры. 368 с.

Этимологический словарь тюркских языков: общетюркские и межтюркские лексические основы на букву “Л”, “М”, “Н”, “П”, “С” (2003) / отв. ред. А. В. Дыбо. М. : Восточная литература РАН. 448 с.

Яковлев, Е. К. (1900) Этнографический обзоръ инородческаго населенія долины Южного Енисея и объяснительный каталогъ этнографическаго отдьла музея. Выпуск 4. Минусинск : Типография В. И. Корнакова. 214 с.

Дата поступления: 02.06.2018 г.

\section{REFERENCES}

Bavuu-Syuryun, M. V. (2005) Struktura toponimov mongol'skogo proiskhozhdeniya na territorii Tuvy [Structure of toponyms of Mongolian origin in the territory of Tuva]. In: Tyva dyldym leksikazynga fakul' tativter [Optional courses in the lexicon of Tuvan language] / Ed. by E. B. Salzynmaa. Kyzyl, Anyyak. 116 p. Pp. 111-115. (In Russ.).

Bol'shoi akademicheskii mongol'sko-russkii slovar' [The Great Academic MongolianRussian Dictionary] (2001a) / Ed. by G. Ts. Pyurbeev. Moscow, ACADEMIA. Vol. I. F-G. 488 p. (In Russ.).

Bol'shoi akademicheskii mongol'sko-russkii slovar' [The Great Academic MongolianRussian Dictionary] (2001b) / Ed. by G. Ts. Pyurbeev. Moscow, ACADEMIA. Vol. II. Д - O. 514 p. (In Russ.).

Bol'shoi akademicheskii mongol'sko-russkii slovar' [The Great Academic MongolianRussian Dictionary] (2001c) / Ed. by G. Ts. Pyurbeev. Moscow, ACADEMIA. Vol. III. $\Theta-\Phi .440$ p. (In Russ.).

Bol'shoi akademicheskii mongol'sko-russkii slovar' [The Great Academic MongolianRussian Dictionary] (2002) / Ed. by G. Ts. Pyurbeev. Moscow, ACADEMIA. Vol. IV. $\mathrm{X}-$ Я. 510 p. (In Russ.).

Bisenbaev, A. K. (2007) Mify drevnikh tyurkov [Myths of ancient Turks]. Almaty, AnArys. 136 p. (In Russ.).

Grach, A. D. (1980) Drevnie kochevniki v tsentre Azii [Ancient nomads in the center of Asia]. Moscow, Nauka. 256 p. (In Russ.). 
Grumm-Grzhimailo, G. E. (2007) Zapadnaya Mongoliya i Uryankhaiskii krai. Antropologocheski i etnograficheskii ocherk etikh stran [Western Mongolia and the Uryankhai krai. An anthropological and ethnographic outline of these countries]. In: Uryankhai. Tyva depter. Antologiya nauchnoi i prosvetitel'skoi mysli o drevnei tuvinskoi zemle i ee nasel'nikakh, ob Uryankhae - Tannu-Tuve, uryankhaitsakh - tuvintsakh, o drevnostyakh Tuvy [Uryankhai. Tyva depter. An anthology of scientific and educational thought about the ancient Tuvan land and its inhabitants, about the Uryankhai-TannuTuva, Uryankhai Tuvans, and the antiquities of Tuva]: in 7 vols. / comp. by S. K. Shoigu. Moscow, Slovo. Vol. 2. Plemena Sayano-Altaya. Uryankhaitsy (IV v. - nachalo XX v.) [The tribes of Sayano-Altai. The Uryankhai (4th - early 20th centuries)]. 664 p. Pp. 496-638. (In Russ.).

Drevnetyurkskii slovar' [An Old Turkic dictionary] (1969) / Ed. by V. M. Nadelyaev et al. Leningrad, Nauka. 676 p. (In Russ.).

Istoriya Tuvy [The History of Tuva] (2001). 2nd ed. / Ed. by S. I. Vainshtein and M. Kh. Mannai-ool. Novosibirsk, Nauka. Vol. 1. 367 p. (In Russ.).

Carruthers, D. (2007) Nevedomaya Mongoliya. Uryankhaiskii krai [Unknown Mongolia. Uryankhai Krai]. vol. 1. / Transl. from Engl. by N. V. Turchaninova. In: Uryankhai. Tyva depter. Antologiya nauchnoi i prosvetitel'skoi mysli o drevnei tuvinskoi zemle i ee nasel'nikakh, ob Uryankhae - Tannu-Tuve, uryankhaitsakh - tuvintsakh, o drevnostyakh Tuvy [Uryankhai. Tyva depter. An anthology of scientific and educational thought about the ancient Tuvan land and its inhabitants, about the Uryanhay-TannuTuva, Uryankhai Tuvans, and the antiquities of Tuva]: in 7 vols. / comp. by S. K. Shoigu. Moscow, Slovo. Vol. 4. Uryankhaiskii krai: perekrestok mnenii (konets XIX - nachalo XX vv.) [Uryanya Autonomous Area: the crossroads of opinions (late 19th - early 20th centuries)]. 552 p. Pp. 10-260. (In Russ.).

Katanov, N. F. (1903) Opyt izsledovaniya uryankhaiskago yazyka, s ukazaniem glavneishikh rodstvennykh otnoshenii ego $k$ drugim yazykam tyurkskago kornya [Experience in the study of the Uryankhai language, indicating the most important of its relations to other Turkic languages]. Kazan', Tipo-litografiya Imperatorskago Kazanskago Universiteta. 547 p. (In Russ.).

Kon, F. Ia. (1934) Za piat'desiat let : Sobranie sochinenii [Over fifty years: Collected Works]: in 3 vol. Moscow, Izd-vo Vses. o-va politkatorzhan i ssyl'no-poselentsev; tip. Profizdata. Vol. 3. Ekspeditsiia v Soiotiiu [Expedition to Soyot]. 293 p. (In Russ.).

Kormushin, I. V. (1997) Tyurkskie eniseiskie epitafii. Teksty i issledovaniya [Turkic Yenisei Epitaphs: Texts and studies] / Ed. by E. R. Tenishev. Moscow, Nauka. 303 p. (In Russ.).

Kormushin, I. V. (2008) Tyurkskie eniseiskie epitafi. Grammatika, tekstologiya [Turkic Yenisei Epitaphs: Grammar and Textology] / Ed. by D. M. Nasilov. Moscow, Nauka. 342 p. (In Russ.). 
Kunaa, A. CH. (1957) Zvukovaya sistema sovremennogo tuvinskogo yazyka [The sound system of modern Tuvan language] / Ed. by Sh. Ch. Sat. Kyzyl, Tipografiya upravleniya kul'tury. 56 p. (In Russ.).

Mannai-ool, M. Kh. (1961) Arkheologicheskie issledovaniya v Ovyurskom raione v 1960 g. [Archaeological research in Ovyur rayon in 1960]. In: Uchenye zapiski TNIIYALI, no. IX / Ed. by N. A. Serdobov et al. Kyzyl, Tip-ya upravleniya kul'tury. 283 p. Pp. 222-229. (In Russ.).

Molchanova, O. A. and Murzaev E. M. (2005) Tyurkskie geograficheskie nazvaniya [Turkic place names]. In: Altaiskoe yazykoznanie i vostochnaya filologiya: Pamyati E. R. Tenisheva [Altai linguistics and oriental philology: In memory of E. R. Tenishev] / Ed. by K. N. Bicheldei et al. Moscow, Vostochnaya literatura RAN. 520 p. Pp. 240-248. (In Russ.).

Ondar, B. K. (1995) Kratkii slovar' gidronimov Tuvy [A Brief Dictionary of Hydronyms of Tuva] / Ed. by I. V. Kormushin. Kyzyl, Tuv. kn. izd-vo. 48 p. (In Russ.).

Ondar, B. K. (1999) S. A. Saryg-oolduң chogaaldarynda toponimner [Toponyms in the works of S. A. Saryg-ool]. In: Yubilei pisatelei. Materialy konferentsii, posvyashhennykh yubileyam pisatelei [Writer's anniversary celebrations. Materials of conferences devoted to the jubilees of writers] / Ed. by S. Kh. Khuren-ool. Kyzyl, RIO TuvGU. 118 p. Pp. 47-50. (In Tuv.).

Ondar, B. K. (2000) Mongolizmy v toponimii Tuvy [Mongolisms in the toponymy of Tuva]. In: Stanovlenie i razvitie nauki v Tuve. Materialy Mezhdunarodnoi konferentsii, posvyashhennoi $k$ 70-letiyu tuvinskoi pis'mennosti $12-14$ sentyabrya 2000 g. [The rise and development of research in Tuva. Proceedings of the International Conference dedicated to the 70th anniversary of Tuvan Writing. September 12-14, 2000] : in 2 vol. / Ed. by Kh. D-N. Oorzhak et al. Kyzyl, RIO TuvGU. Vol. 1. 140 p. Pp. 56-57. (In Russ.).

Ondar, B. K. (2001) Nekotorye paralleli v toponimii Tyvy i Khakassii [Some parallels between the toponymy of Tuva and Khakassia]. In: Aktual'nye problemy sokhraneniya i razvitiya yazykov, kul'tur i istorii Sayano-Altaya [Urgent issues of preservation and development of languages, cultures and history of the Sayano-Altai]. Proceedings of the international conference dedicated to the 280th anniversary of the deciphering of the old Turkic writing / Ed. by S. P. Ulturgashev and L. I. Chebodaeva. Abakan, Izd-vo KhGU im. N. F. Katanova. 262 p. Pp. 120-124. (In Russ.).

Ondar, B. K. (2003) Tabu i evfemizmy v tyvinskoi toponimii [Taboo and euphemisms in Tuvan toponymy]. Vestnik Khakasskogo gosudarstvennogo universiteta im. N. F. Katanova, issue 5. Filologiya: Yazykoznanie, no. 5; issue 6. Filologiya: Literaturovedenie, no. 2, pp. 38-41. (In Russ.).

Ondar, B. K. (2004) Toponimicheskii slovar' Tuvy [A Toponymical dictionary of Tuva]. Abakan, Izd-vo KHGU im. N.F. Katanova. 254 p. (In Russ.) 
Ondar, B. K. (2005) Istochniki po tuvinskoi toponimike [Sources on Tuvan toponymy]. In: Gumanitarnaya nauka Tuvy na styke vekov: istoriya, problemy i perspektivy razvitiya [Humanitarian research of Tuva at the turn of the century: history, problems and development prospects]: Papers presented at the conference dedicated to the 75th anniversary of the Tuvan writing and the 60th anniversary of the TIIIIILI-TIGI). October 13-14, 2005. Kyzyl, Tip. KTSO Anyyak. 136 p. Pp. 65-70. (In Russ.).

Ondar, B. K. (2006) O nekotorykh nazvaniyakh arzhaanov Tyva (sravnitel'nosopostavitel'nyj analiz) [On some names of Tuvan arzhaans: a comparative analysis)]. In: Ertem bizhikteri. 1-gi yndyrylgezi / Uchenye zapiski: Ezhegodnik kafedry tuvinskogo i obshhego yazykoznaniya TyvGU, no. 1, pp. 51-59. (In Russ.).

Ondar, B. K. (2007) Toponimicheskii slovar' Tuvy [A Toponymical dictionary of Tuva]. 2nd ed. Kyzyl, Tuv. kn. izd-vo. 550 p. (In Russ.).

Ondar, B. K. (2008a) Tuvinskaya toponimiya. Sopostavitel'nyj analiz toponimii Tuvy s toponimiei Yuzhnoi Sibiri i drugikh tyurkoyazychnykh territorii [The toponymy of Tuva: A comparative analysis of the toponymy of Tuva and that of Southern Siberia and other Turkic-speaking territories]. Kyzyl, Tuv. kn. izd-vo. 304 p. (In Russ.).

Ondar, B. K. (2008b) Tuvinskaya toponimika: problemy, poiski, resheniya. Problemy prepodavaniya russkogo yazyka $v$ vuze i $v$ shkole [Tuvan toponymy: problems, investigations, solutions. The problems of teaching Russian in the university and at school]. Kyzyl, RIO TuvGU. 233 p. (In Russ.).

Potanin, G. N. (2007) Ocherki Severo-Zapadnoi Mongolii. Rezul'taty puteshestviya, ispolnennogo v 1876-1877 godakh po porucheniyu Imperatorskogo Russkogo Geograficheskogo Obshhestva [Essays on North-West Mongolia. The results of the journey, executed in 1876-1877 on behalf of the Imperial Russian Geographical Society]. Vypusk II. Materialy etnograficheskie. St. Petersburg. In: Uryankhai. Tyva depter. Antologiya nauchnoi i prosvetitel'skoi mysli o drevnei tuvinskoi zemle i ee nasel'nikakh, ob Uryankhae - Tannu-Tuve, uryankhaitsakh - tuvintsakh, o drevnostyakh Tuvy [Uryankhai. Tyva depter. An anthology of scientific and educational thought about the ancient Tuvan land and its inhabitants, about the Uryankhai-Tannu-Tuva, Uryankhai Tuvans, and the antiquities of Tuva]: in 7 vols. / sost. S.K. Shoigu. Moscow, Slovo. Vol. 2. Plemena Sayano-Altaya. Uryankhaitsy (IVv. - nachalo XX vv.) [The tribes of Sayano-Altai. Uryankhaitsy (4th - early XX centuries)]. 664 p. Pp. 496-638. (In Russ.).

Potanina, A. V. (2003) Iz puteshestvii po Vostochnoi Sibiri, Mongolii, Tibetu i Kitayu. Moskva. Iz stranstvii po Uryankhaiskoi zemle [From travels to Eastern Siberia, Mongolia, Tibet and China. Moscow. From the wanderings in the Uryankhai lands]. In: Traditsionnaya kul'tura tuvintsev glazami inostrantsev (konets XIX - nachalo XX vv.) [Traditional culture of Tuvan people through the eyes of foreigners (late 19th - early 20th centuries)] / Comp. by A. K. Kuzhuget. Kyzyl, Tuv.kn. izd-vo. 224 p. Pp. 29-38. (In Russ.).

Rassadin, V. I. (1971) Fonetika i leksika tofalarskogo yazyka [Phonetics and vocabulary of Tofalar language] / Ed. by Ts. B. Tsydendambaev. Ulan-Ude, Buryatskoe kn. izd-vo. 252 p. (In Russ.). 
Rassadin, V. I. (1995) Tofalarsko-russkii, russko-tofalarskii slovar' [A Tofalar-Russian and Russian-Tofalar dictionary] / Ed. by I. D. Buraev. Irkurtsk, Vostochno-Sibirskoe kn. izd-vo. 288 p. (In Russ.).

Rodevich, Vs. (2003) Uryankhaiskii krai i ego obitateli [The Uryankhai krai and its inhabitants]. In: Traditsionnaya kul'tura tuvintsev glazami inostrantsev (konets XIXnachalo XX vv.) [Traditional culture of Tuvan people through the eyes of foreigners (late 19th - early 20th centuries)] / Comp. by A. K. Kuzhuget. Kyzyl, Tuv.kn. izd-vo. 224 p. Pp. 136-141. (In Russ.).

Rozental', D. E. and Telenkova, M. A. (2001) Slovar'-spravochnik lingvisticheskikh terminov [A Dictionary and Reference Book of Linguistic Terminology]. Moscow, Astrel', AST. 624 p. (In Russ.).

Sat, Sh. Ch. (1969) Zametki po toponimii Tuvy [Notes on the toponymy of Tuva]. In: Materialy konferentsii «Etnogenez narodov Severnoi Azii» [Ethnogenesis of the Peoples of North Asia: Proceedings of a conference] / Ed. by. E. I. Ubryatova. Novosibirsk, s. n. 247 p. Pp. 232-234. (In Russ.).

Sat, Sh. Ch. (1987) Tyva dialektologiya [Tuvan dialectology] / Ed. by E. B. Salzynmaa. Kyzyl, TNYCH. 104 p. (In Tuv.).

Sevortyan, E. V. (1974) Etimologicheskii slovar' tyurkskikh yazykov: obshhetyurkskie i mezhtyurkskie osnovy na glasnye [An Etymological dictionary of Turkic languages: common Turkic and inter-Turkic vowel stems] / Ed. by R. M. Zaleskovskaya. Moscow, Nauka. 768 p. (In Russ.)

Sevortyan, E. V. (1978) Etimologicheskii slovar' tyurkskikh yazykov: obshhetyurkskie i mezhtyurkskie osnovy na bukvu " $B$ " [An Etymological dictionary of Turkic languages: common Turkic and inter-Turkic stems, letter "B"] / Ed. by N. Z. Gadzhieva. Moscow, Nauka. 352 p. (In Russ.).

Sevortyan, E. V. (1980) Etimologicheskii slovar' tyurkskikh yazykov: obshhetyurkskie i mezhtyurkskie osnovy na bukvy "V", "G", " $D$ " [An Etymological dictionary of Turkic languages: common Turkic and inter-Turkic stems, letters " $V$ ", "G", " $D$ "] / Ed. by N. Z. Gadzhieva. Moscow, Nauka. 396 p. (In Russ.).

Sravnitel'no-istoricheskaya grammatika tyurkskikh yazykov. Leksika [A comparativehistorical grammar of Turkic languages: Vocabulary] (2001) / Ed. by E. R. Tenishev. Moscow, Nauka. 824 p. (In Russ.).

Sravnitel'no-istoricheskaya grammatika tyurkskikh yazykov. Regional'nye rekonstruktsii [A Comparative-historical grammar of Turkic languages: Regional Reconstructions] (2002) / Ed. by E. R. Tenishev. Moscow, Nauka. 767 p. (In Russ.).

Suvandii, N. D. (2004) Tuvinskaya antroponimiya [Tuvan anthroponymy] : Thesis of Diss.... Candidate of Philology. Moscow, Kyzyl. 21 p. (In Russ.).

Suvandii, N. D. (2013) Sovremennoe sostoyanie izucheniya onomastiki tuvinskogo yazyka [The modern state of studying the onomastics of Tuvan language]. Mir nauki, kul'tury, obrazovaniya, no. 6 (43), pp. 362-364. (In Russ.). 
Suvandii, N. D. (2015) Stanovlenie familii i otchestv v tuvinskom yazyke [Formation of surnames and patronymics in Tuvan language]. Filologicheskie nauki. Voprosy teorii i praktiki, no. 12(54), vol. I, pp. 171-173. (In Russ.).

Tatarintsev, B. I. (1977a) Mestnye geograficheskie terminy Severo-Vostochnoi Tuvy [Local geographical terms of the North-Eastern Tuva]. Sovetskaya tyurkologiya, no. 5, pp. 18-26. (In Russ.).

Tatarintsev, B. I. (1977b) O toponimii basseina r. Kaa-Khem [On the toponymy of the Kaa-Khem river basin]. In: Tuvinskii yazyk i literatura $v$ posleoktyabr'skii period [Tuvan language and literature in the post-October period]. Kyzyl, Tip-iya upravleniya po delam izdatel'stv, poligrafii i knizhnoi torgovli Soveta Ministrov Tuv. ASSR. 192 p. Pp. 88-98. (In Russ.).

Tatarintsev, B. I. (1993) O nekotorykh drevnikh toponimakh tyurkskogo proiskhozhdeniya na territorii Tuvy [On some old toponyms of Turkic origin on the territory of Tuva]. In: Voprosy tuvinskogo yazykoznaniya [Questions of Tuvan linguistics] / Ed. by D. A. Mongush and B. I. Tatarintsev. Kyzyl, Novosti Tuvy. 128 p. Pp. 105-113. (In Russ.).

Tatarintsev, B. I. (1973) Ob osobennostyakh toponimii Severo-Vostochnoi Tuvy [On the peculiarities of the toponymy of the North-Eastern Tuva]. In: Proiskhozhdenie aborigenov Sibiri i ikh yazykov [The origin of the aborigines of Siberia and their languages]: Materials of the All-Union Conference June 14-16, 1973]. Tomsk, Izd-vo Tomskogo universiteta. 235 p. Pp. 142-144. (In Russ.).

Tatarintsev, B. I. (2000) Etimologicheskii slovar' tuvinskogo yazyka [An etymological dictionary of the Tuvan language]. Novosibirsk, Nauka. Vol. I. A-B. 341 p. (In Russ.).

Tatarintsev, B. I. (2002) Etimologicheskii slovar' tuvinskogo yazyka [An etymological dictionary of the Tuvan language]. Novosibirsk, Nauka. Vol. II. D-J. 388 p. (In Russ.).

Tolkovyj slovar' tuvinskogo yazyka [An Explanatory dictionary of Tuvan language] (2003) / Ed. by D. A. Mongush. Novosibirsk, Nauka. Vol. I. A-Й. 600 p. (In Russ.).

Tolkovyj slovar' tuvinskogo yazyka [An Explanatory dictionary of Tuvan language] (2011) / Ed. by D. A. Mongush. Novosibirsk, Nauka. Vol. II. K-C. 800 p. (In Russ.).

Tuvinsko-russkii slovar': 22000 slov [A Tuvan-Russian dictionary. C. 20,000 words] (1968) / Ed. by E. R. Tenishev. Moscow, Sovetskaya entsiklopediya. 648 p. (In Tuv. and Russ.).

Etimologicheskii slovar' tyurkskikh yazykov: obshhetyurkskie i mezhtyurkskie osnovy na bukvu "K", "K" [An etymological dictionary of Turkic languages: common Turkic and inter-Turkic stems, the letters " $K$ ", “ $K$ "] (1997) / Ed. by G. F. Blagova. Moscow, Yazyki russkoi kul'tury. 368 p. (In Russ.).

Etimologicheskii slovar' tyurkskikh yazykov: obshhetyurkskie i mezhtyurkskie leksicheskie osnovy na bukvu " $L$ ", "M", " $N$ ", "P", "S" [An etymological dictionary of Turkic languages: common Turkic and inter-Turkic stems, the letters "L", “ $M$ ", “N”, "P”, "S"] (2003) / Ed. by A. V. Dybo. Moscow, Vostochnaya literatura RAN. 448 p. (In Russ.). 
Yakovlev, E. K. (1900) Etnograficheskii obzor inorodcheskago naseleniya doliny Yuzhnogo Eniseya i obyasnitel' nyi katalog etnograficheskago otdela muzeya [Ethnographic survey of the non-Russian population of the Southern Yenisei valley and the explanatory catalog of the museum's ethnographic department]. Vol. 4. Minusinsk, Tipografiya V. I. Kornakova. 214 p. (In Russ.).

Submission date: 12.06 .2018 .

\section{Для цитирования:}

Кара-оол Л. С. Лексические особенности топонимов Овюрского района Тувы [Электронный ресурс] // Новые исследования Тувы. 2018, № 3. URL: https://nit.tuva. asia/nit/article/view/795 (дата обращения: дд.мм.гг.). DOI: 10.25178/nit.2018.3.11

\section{For citation:}

Kara-ool L. S. Lexical features of microtoponyms of Ovyur rayon of Tuva. The New Research of Tuva, 2018, no. 3 [on-line] Available at: https://nit.tuva.asia/nit/article/view/795 (accessed: ). DOI: 10.25178/nit.2018.3.11 